\title{
Aktivitas Daya Hambat Limbah Daging Buah Kopi Robusta ( Coffea robusta L.) Aceh terhadap Bakteri S.aureus dan E.coli
}

\author{
Muhammad Ridwan Harahap \\ Fakultas Sains dan Teknologi, Universitas Islam Negeri Ar-Raniry Banda Aceh, Indonesia \\ Email: ridwankimia@ar-raniry.ac.id
}

\begin{abstract}
Inhibitory Activity of S. aureus and E. coli bacteria of a waste of Aceh's Robusta fruit flesh. Coffee fruit flesh is a waste that coffee farmers use as animal feed only, even though has a composition such as carbohydrates, proteins, fiber, minerals, water, protein, caffeine, and polyphenols. These compositions are very useful for cosmetic and pharmaceutical industries. This study was a research on the use of waste of Aceh's Robusta fruit flesh (Coffea robusta) on the ability to inhibit the bacteria $\mathrm{S}$-aureus and E.coli as the basic ingredients of the cosmetic face mask of halal products. The samples used were from Takengon city. The skin of the coffee beans was peeled, cleaned and extracted with methanol for about $3 \times 24$ hours. Further concentrated until obtained extract concentrated. The resulting extracts were tested phytochemically. Variations of extracts concentration on water solvents were $1 \%, 2 \%$, and $3 \%$. The antibacterial activity was tested by the diffusion method which used the disc. The result showed inhibitory zone to E.coli bacteria at $1 \%, 2 \%, 3 \%$ concentration were $6,5 \mathrm{~mm}, 7.2 \mathrm{~mm}$ and $7.8 \mathrm{~mm}$ respectively. While in S.aureus at a concentration of $1 \%, 2 \%, 3 \%$ were $15.1 \mathrm{~mm}, 15.3 \mathrm{~mm}$ and $15.5 \mathrm{~mm}$ respectively. The best variation of the concentration of Robusta coffee fruit flesh extract (Coffea robusta) in this study on the growth of S-aureus and E.coli bacteria was $3 \%$.
\end{abstract}

Keywords: Antibacterial, E.coli, fruit flesh of coffee, S. aureus

\begin{abstract}
Abstrak: Aktivitas Daya Hambat Limbah Daging Buah Kopi Robusta (Coffea robusta L.) Aceh terhadap Bakteri S.aureus dan E.coli. Daging buah kopi merupakan limbah yang dimanfaatkan petani kopi hanya sebagai pakan ternak saja. Padahal memiliki komposisi seperti karbohidrat, protein, fiber, mineral, air, protein, kafein dan polifenol. Komposisi tersebut sangat berguna untuk industri kosmetik dan farmasi. Telah dilakukan penelitian tentang pemanfaatan limbah daging buah kopi robusta (coffea robusta) Aceh terhadap kemampuan menghambat bakteri $S$-aureus dan E.coli sebagai bahan dasar pembuatan kosmetik masker wajah produk halal. Sampel yang digunakan berasal dari kota Takengon. Limbah kulit biji kopi dikupas dan dibersihkan lalu diekstraksi dengan metanol selama lebih kurang 3x24 Jam. Selanjutnya dipekatkan sampai diperoleh ekstrak pekat. Ekstrak yang dihasilkan diuji secara fitokimia kemudian variasi konsentrasi terhadap pelarut air yaitu 1\%,2\% dan 3\%. Untuk aktivitas antibakteri dari ekstrak yang sudah diperoleh akan diuji dengan metode difusi agar menggunakan cakram. Hasil yang diperoleh menunjukkan terhadap bakteri E.coli pada konsentrasi $1 \%$ sebesar $6,5 \mathrm{~mm}$; $2 \%$ sebesar $7,2 \mathrm{~mm}$ dan $3 \%$ sebesar $7,8 \mathrm{~mm}$. Sedangkan terhadap bakteri S.aureus pada konsentrasi $1 \%$ sebesar 15,1 mm; $2 \%$ sebesar 15,3 mm dan 3\% sebesar 15,5 mm. Variasi terbaik dari konsentrasi pada ekstrak daging buah kopi Robusta (coffea robusta) pada penelitian ini terhadap pertumbuhan bakteri S-aureus dan E.coli adalah dengan konsentrasi $3 \%$.
\end{abstract}

Kata kunci: Anti bakteri, Daging buah kopi, E.coli, S.aureus

Provinsi Aceh merupakan provinsi yang terletak pada bagian barat Indonesia. Komoditas dari provinsi Aceh salah satunya adalah penghasil kopi. Kopi yang terkenal dari Aceh adalah jenis Robusta (coffea robusta) dan Arabika (coffea arabic). Hal ini sejalan dengan kebiasaan masyarakat Aceh yang gemar minum kopi baik di pagi hari maupun malam hari, sehingga produksi tumbuhan kopi terus meningkat di provinsi Aceh.
Budi daya tanaman kopi merupakan komoditas lokal masyarakat yang tinggal di daerah dataran tinggi. Sesuai data Dinas Pertanian Aceh Tengah tahun 2016 tentang produksi kopi di Aceh mengalami peningkatan rata-rata sebesar 31.375 ton sedangkan tahun tahun sebelum nya hanya berkisar 27.777 ton pertahun. Tidak diperlukan teknik khusus untuk membudidayakan tumbuhan ini(Suwarto \& Octavianty, 2010). Hanya saja yang perlu 
diperhatikan kondisi lingkungan dan tingkat kelembaban udara agar hasil buah kopi yang diperoleh saat panen menjadi lebih optimal (Najiyati \& Danarti, 2001).

Dalam pembuatan kopi khas Aceh yang dibutuhkan hanya sebatas biji kopi saja, sedangkan daging buah kopi tidak digunakan. Daging buah kopi tersebut dianggap limbah padahal daging buah kopi mengandung senyawa antioksidan dalam jumlah yang cukup banyak. Kegunaan antioksidan dapat membantu tubuh dalam menangkal efek perusakan oleh senyawa radikal bebas, seperti kanker, diabetes, dan penurunan respon imun (Harmandini, 2009). Beberapa contoh senyawa antioksidan yang terdapat di dalam kopi adalah kafein, polifenol, flavonoid, proantosianidin, kumarin, asam klorogenat, dan tokoferol. (Mahesa, 2012) Dengan perebusan, aktivitas antioksidan ini dapat ditingkatkan (Watson, 2014).

Limbah dari daging buah kopi selama ini hanya dimanfaatkan petani sebagai pakan ternak saja. Jika dilihat dari komposisi buah kopi tersebut, sangat banyak manfaat yang dihasilkan dari limbah tersebut. Perbandingan sederhana dari buah kopi yang dihasilkan dapat dilihat bahwa satu kilogram buah kopi terdapat tiga ratus gram limbah daging buah kopi (1:0,3) (Pujiyanto, 2007).

Didalam buah kopi terdapat komposisi penyusun buah yang terdiri dari skin, pulp, parchment. Secara umumnya adalah karbohidrat $(35 \%)$, protein $(5,2 \%)$, fiber $(30,8 \%)$ dan mineral $(10,7 \%)$ sedangkan bagian mucilage mengandung air $(84,2 \%)$, protein $(8,9 \%)$, gula $(4,1 \%)$ dan abu $(0,7 \%)$. Selain itu, kulit biji kopi ini juga mengandung beberapa senyawa metabolit sekunder yaitu seperti dari kafein dan golongan polifenol. Dari beberapa penelitian, senyawa polifenol yang ada pada limbah ini adalah flavan3-ol, asam hidroksinamat, flavonol, antosianidin, katekin, epikatekin, rutin,tanin, asam ferulat (Widyotomo \& Sri, 2007).

Beberapa penelitian tentang penggunaan daging buah kopi sudah dilakukan diantaranya penelitian tentang pemanfaatan kulit buah kopi dan bahan mineral sebagai amelioran tanah alami. Hasil yang diperoleh adalah amelioran kulit buah kopi dapat meningkatkan pertumbuhan bibit kopi secara efektif dan meningkatkan pertumbuhan tanaman serta meningkatkan keefektifan pupuk anorganik apabila dilakukan kombinasi (Pujiyanto 2007).

Penelitian lain yang melibatkan lebih dari 67.000 wanita, tentang hubungan minum biji kopi dengan kejadian kanker kulit pada wanita. Hasil yang diperoleh menunjukkan bahwa wanita yang minum lebih dari empat cangkir kopi per hari dapat menurunkan 25 persen risiko kanker endometrium. Wanita yang minum dua sampai tiga cangkir per hari dapat mengurangi resiko yang sebesar 7\% (Je et al. 2011).

Buah kopi memiliki senyawa antioksidan yang berfungsi sebagai pengikat senyawa radikal bebas. Senyawa polifenol yang dihasilkan dari proses ekstraksi mampu mengurangi kadar logam dan membunuh bakteri penyebab penyakit seperti S.aureus dan E.coli (Patay et al., 2016).

S.aureus merupakan kelompok bakteri gram positif karena memiliki dinding sel dengan ketebalan 15-80 $\mathrm{nm}$ dan berlapis tunggal. S. aureus berbentuk bulat dan dapat tumbuh secara optimum pada suhu $37^{\circ} \mathrm{C}$ dan memiliki ukuran yang berbeda-beda tergantung pada media pertumbuhannya. Sedangkan E.coli merupakan bakteri yang menyebabkan penyaki diare dan iritasi luka pada kulit. E.coli merupakan kelompok bakteri gram negatif yang berbentuk batang pendek dan panjangnya sekitar $2 \mu \mathrm{m}$, diameter $0,7 \mu \mathrm{m}$, lebar $0,4-0,7 \mu \mathrm{m}$ (va Brigitta Patay et al. 2016). E. coli umumnya hidup dalam saluran pencernaan manusia dan dapat menyebabkan penyakit disentri. Bakteri tersebut banyak ditemukan pada partikel udara dan menempel pada debu (Pelczar \& Chan 1988). Untuk mengatasi masalah tersebut dilakukan penelitian kesehatan kulit untuk mencegah paparan bakteri tersebut (Draelos 2014).

Masker wajah merupakan produk kecantikan yang berguna sebagai pelindung wajah untuk mengatasi paparan langsung dari sinar matahari dan butiran debu. Masker yang baik mampu memberikan perlindungan dari bakteri yang melekat pada debu sehingga dapat mencegah penyakit kulit seperti jerawat dan penuaan lapisan epidermis dibandingkan dengan kulit wajah yang tidak menggunakan masker.

Tujuan dilakukannya penelitian ini diharapkan penggunaan daging buah kopi dapat dimanfaatkan sebagai antioksidan penghambat laju aktivitas bakteri sebagai bahan dasar pembuatan kosmetik masker wajah. Untuk tahap awal penulis melakukan penelitian terhadap Aktivitas Daya Hambat Limbah Daging Buah Kopi Robusta (Coffea robusta L.) Aceh terhadap Bakteri S.aureus dan E.coli.

\section{METODE}

Penelitian ini bersifat eksperimental laboratorium. Penelitian dilakukan bulan November 2016-Mei 2017 di Universitas Islam Negeri Ar-Raniry Banda Aceh dan laboratorium 
Kimia Analitik Universitas Sumatera Utara. Pada pemilihan sampel yang digunakan berasal dari wilayah Kabupaten Aceh Tengah Kota Takengon dikarenakan buah kopi yang dihasilkan memiliki ciri khas tersendiri dan sudah menjadi komoditi ekspor daerah tersebut. Pada proses isolasi senyawa aktif pada limbah daging buah kopi ini dilakukan 5 tahapan prosedur. Harborne, J.B., 1984, mengemukakan tahapan analisis untuk senyawa metabolit sekunder yang berasal dari tumbuhan meliputi metode ekstraksi, evaporasi, kromatografi dan pengujian skrining fitokimia (Harborne 1984).

\section{Alat dan bahan}

Peralatan yang digunakan meliputi alat-alat gelas, Fourier-Transform InfraRed (FTIR), neraca analitik, inkubator, rotari evaporator.

Bahan yang digunakan meliputi Metanol, $\mathrm{KI}, \mathrm{HgCl}_{2}, \mathrm{CH}_{3} \mathrm{COOH}, \mathrm{H}_{2} \mathrm{SO}_{4}$, kloramfenikol, biakan bakteri E.coli dan S. aureus, akuades.

\section{Prosedur Kerja}

\section{Metode Ekstraksi dan Evaporasi}

Daging biji kopi yang telah dikupas ditimbang sebanyak 800 gram kemudian diekstraksi dengan metanol selama lebih kurang 3 hari. Penggunaan metanol dikarenakan tingkat kepolaran pelarut tersebut hampir mendekati dengan senyawa yang ingin diekstrasi. Setelah didapatkan ekstraknya selanjutnya dipekatkan dengan rotari evaporator sehingga didapatkan ekstrak pekat. Ekstrak pekat kulit biji kopi dituang ke dalam cawan petri kaca. Lalu dimasukkan kedalam inkubator pada suhu $37{ }^{\circ} \mathrm{C}$ selama 24 jam dengan perbandingan terhadap akuades $1 \%, 2 \%$ dan $3 \%$.

\section{Metode Skrining Fitokimia}

Ekstrak yang sudah dipekatkan dilakukan uji skrining fitokimia untuk menentukan jenis alkaloid, flavonoid atau terpenoid. Lalu diuji dengan menggunakan instrumen FTIR untuk menentukan jenis senyawa aktif yang terkandung didalamnya. Kemudian ditentukan senyawa aktif yang berperan dalam menghambat bakteri (Suoth et al. 2013).

\section{Uji Aktivitas Bakteri}

Ekstrak yang dihasilkan kemudian
digunakan untuk menguji terhadap
perkembangbiakan bakteri S.aureus sebagai uji
aktivitas bakteri gram positif dan bakteri E.coli
sebagai aktivitas bakteri gram negatif sedangkan
kloramfenikol merupakan kontrol positif dan
akuades sebagai kontrol negatif terhadap aktivitas
perkembangbiakan bakteri. Hasil yang diperoleh akan terlihat perkembangan bakteri-bakteri tersebut pada media ekstrak yang diperoleh (Abdillah et al. 2015).

\section{HASIL}

\section{Metode Ekstraksi}

Metode pemisahan yang telah dilakukan terhadap limbah daging kulit biji kopi (sampel) adalah metode maserasi. Limbah kulit biji kopi dikupas dan dibersihkan. Daging biji kopi yang telah dikupas sebanyak 800 gram diekstraksi dengan metanol selama lebih kurang 3x24 Jam. Setelah didapatkan ekstraknya selanjutnya dipekatkan dengan rotari evaporator sehingga didapatkan ekstrak pekat. Ekstrak yang diperoleh berwarna kuning kecoklatan sebanyak 45,5 mL. Rendemen hasil yang diperoleh sebesar 5,68\%.

Tabel 1. Hasil Ekstraksi Daging Buah kopi dengan Pelarut Metanol

\begin{tabular}{lcccc}
\hline Sampel & $\begin{array}{c}\text { Berat } \\
\text { Kering } \\
(\mathbf{g})\end{array}$ & $\begin{array}{c}\text { Berat } \\
\text { Ekstrak } \\
\text { Metanol } \\
(\mathbf{m L})\end{array}$ & $\begin{array}{c}\text { Berat } \\
\text { Rendemen } \\
(\%)\end{array}$ & $\begin{array}{c}\text { Warna } \\
\text { Ekstrak }\end{array}$ \\
\hline $\begin{array}{l}\text { Daging } \\
\text { buah } \\
\text { Kopi }\end{array}$ & 800 & 45,5 & 5,68 & $\begin{array}{c}\text { Kuning } \\
\text { kecoklatan }\end{array}$ \\
\hline
\end{tabular}

\section{Metode Skrining Fitokimia}

Ekstrak daging buah kopi yang telah diperoleh kemudian dimasukkan kedalam plat tetes porselen. Ekstrak yang dihasilkan diuji secara fitokimia untuk mengetahui kandungan metabolit sekunder yang terkandung di dalamnya. Hasil uji fitokimia dapat dilihat pada tabel berikut :

\section{Tabel 2. Hasil Uji Fitokimia Ekstrak Daging Buah Kopi}

\begin{tabular}{ccccc}
\hline \multirow{2}{*}{ Sampel } & \multicolumn{4}{c}{ Metabolit Sekunder } \\
\cline { 2 - 5 } & Alkaloid & $\begin{array}{c}\text { Flavo- } \\
\text { noid }\end{array}$ & $\begin{array}{c}\text { Terpe- } \\
\text { noid }\end{array}$ & $\begin{array}{c}\text { Uji } \\
\text { Polifenol }\end{array}$ \\
\hline $\begin{array}{l}\text { Ekstrak daging } \\
\text { buah kopi }\end{array}$ & + & + & - & + \\
\hline
\end{tabular}

Ekstrak yang telah diperoleh dan diuji menggunakan Fourier Transform Infrared Spectroscopy (FTIR) untuk menentukan gugus fungsi yang terdapat pada sampel. Spektrum yang dihasilkan berupa bukit dan lembah. Masingmasing spektrum mewakili gugus fungsi yang terdapat pada sampel. Spektrum FTIR digunakan untuk mengidentifikasi gugus fungsi dari senyawa-senyawa yang aktif dimunculkan dalam 
bentuk area tertentu dari radiasi gelombang inframerah. Dengan data spektrum yang diperoleh dapat disimpulkan sementara bahwa sampel yang diperoleh sesuai dengan literatur maupun ciri khas suatu senyawa.

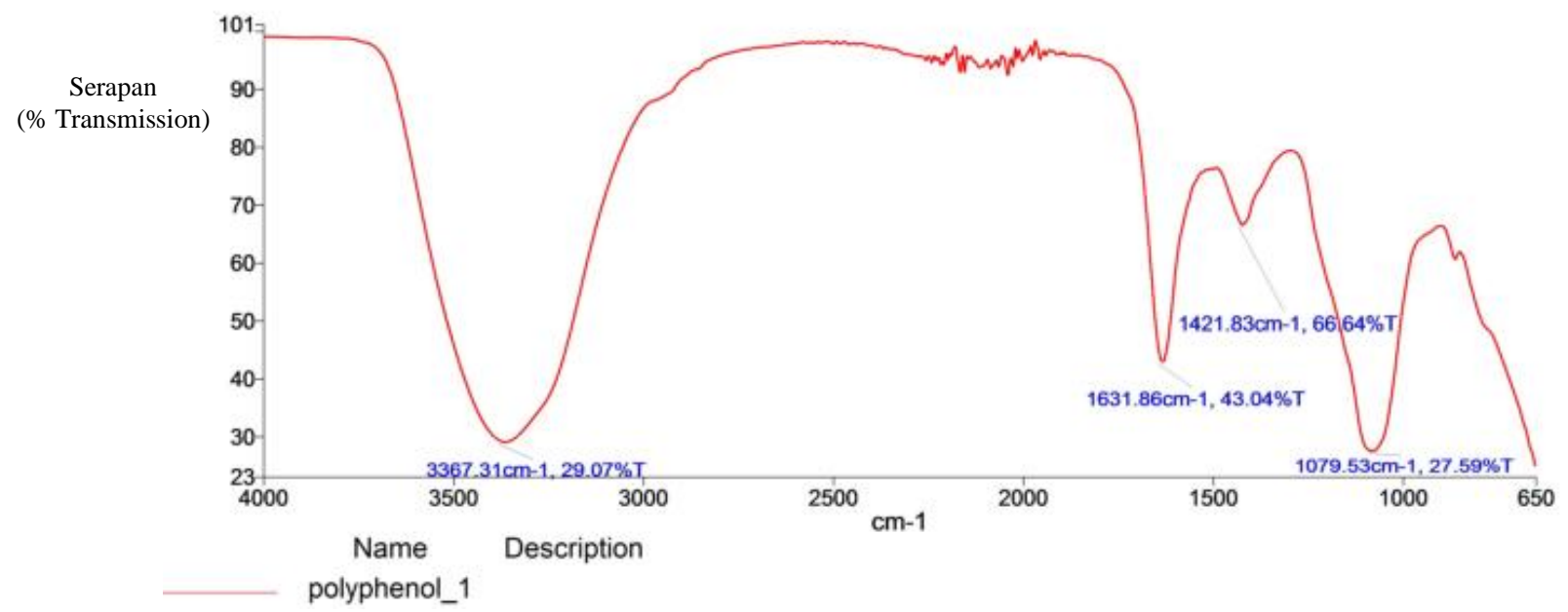

Gambar 1. Grafik Spektrum FTIR ekstrak daging buah kopi (Robusta coffee)

\section{Ui Aktivitas Bakteri}

Aktivitas antibakteri dari ekstrak yang sudah diperoleh akan diuji dengan metode difusi agar menggunakan cakram. Cakram yang telah berisi larutan uji, kontrol positif (kloramfenikol $30 \mu \mathrm{g} / \mathrm{mL}$ atau antibiotik) serta kontrol negatif (akuades) diletakkan di atas media agar yang telah melalui kultur jaringan dengan bioindikator $E$. coli dan $S$. aureus. Penggunakan kloramfenikol sebagai kontrol positif dikarenakan memiliki spektrum luas, sehingga mampu menghambat bakteri gram positif dan gram negatif, sedangkan akuades digunakan sebagai kontrol negatif untuk melihat ada atau tidaknya pengaruh pelarut dalam menghambat pertumbuhan E. coli dan $S$. aureus. Larutan uji yang digunakan yaitu ekstrak yang dibuat dalam 3 variasi konsentrasi yaitu $1 \%, 2 \%$, dan $3 \%$. Pengamatan dilakukan sebanyak 1 kali tanpa dilakukan perulangan. Kemampuan antibakterial ekstrak diperlihatkan dengan adanya daerah hambat di sekitar cakram.

Hasil yang diperoleh dapat dilihat pada gambar berikut:

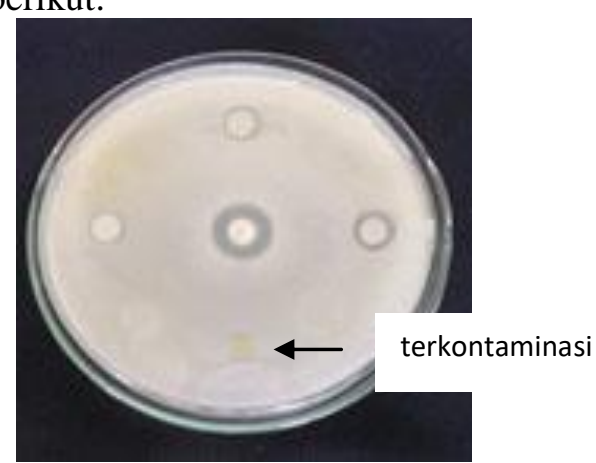

(a)

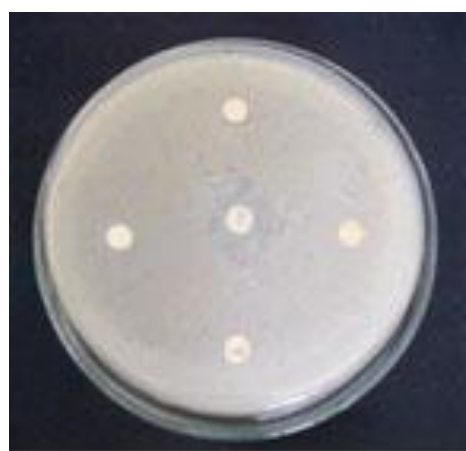

(b)

Gambar 2. (a) Aktivitas bakteri E.coli (Uji Gram negatif) dan (b) S.aureus (Uji Gram positif)

Aktivitas ekstrak daging buah kopi terhadap bioindikator $E$. coli dapat dilihat pada tabel berikut:

Tabel 3. Daerah Hambat Ekstrak Daging Buah Kopi (Robusta coffea) terhadap Bakteri E. coli dan S.aureus

\begin{tabular}{|c|c|c|c|c|c|c|}
\hline \multirow[t]{3}{*}{ Sampel } & \multirow[t]{3}{*}{ Bakteri } & \multicolumn{5}{|c|}{$\begin{array}{c}\text { Diameter daerah hambatan rata-rata } \\
(\mathbf{m m})\end{array}$} \\
\hline & & \multirow{2}{*}{$\begin{array}{c}\text { Kontrol } \\
(+)\end{array}$} & \multirow{2}{*}{$\begin{array}{c}\text { Kontrol } \\
(-)\end{array}$} & \multicolumn{3}{|c|}{$\begin{array}{r}\text { Konsentrasi } \\
\text { ekstrak (b/v) }\end{array}$} \\
\hline & & & & $1 \%$ & $2 \%$ & $3 \%$ \\
\hline \multirow{2}{*}{$\begin{array}{l}\text { Ekstrak } \\
\text { daging } \\
\text { buah }\end{array}$} & E. coli & 15 & 6 & 6,5 & 7,2 & 7,8 \\
\hline & $\begin{array}{c}\text { S. } \\
\text { aureus }\end{array}$ & 20 & 6 & 15,1 & 15,3 & 15,5 \\
\hline
\end{tabular}

kopi

Keterangan tabel 3: Diameter cakram $=6 \mathrm{~mm}$, Kontrol $(+)=$ kloramfenikol $30 \mu \mathrm{g} / \mathrm{mL}$ (antibiotik), Kontrol $(-)=$ akuades. 


\section{PEMBAHASAN}

Dari hasil skrining fitokimia menunjukkan bahwa pada daging buah kopi mengandung senyawa metabolit sekunder alkaloid, flavonoid dan polifenol. Beberapa literatur menjelaskan bahwa kandungan lain banyak terdapat dalam daging buah tersebut seperti golongan terpenoid, hanya saja dalam jumlah yang relatif kecil sehingga sulit terdeteksi dengan analisis kualitatif (Harborne 1984).

Data skrining fitokimia yang diperoleh menggambarkan bentuk yang khas dari senyawa polifenol. Daerah yang dihasilkan adalah 3367,31 $\mathrm{cm}^{-1} ; 1631,86 \mathrm{~cm}^{-1} ; 1421,83 \mathrm{~cm}^{-1}$; dan 1079,53 $\mathrm{cm}^{-1}$. Hasil tersebut menunjukkan bahwa gugus OH pada bilangan panjang gelombang 3600-2800 $\mathrm{cm}^{-1}$ dengan lembah pada $3367,31 \mathrm{~cm}^{-1}$ ini menunjukkan pelebaran pita yang merupakan ciri khas dari gugus $\mathrm{OH}$. Pada panjang gelombang $1631,86 \mathrm{~cm}^{-1}$ menunjukkan adanya pergerakan kelompok gugus karbonil $\mathrm{C}=\mathrm{O}$ tersambungkan dengan gugus amida. Untuk panjang gelombang $1421,83 \mathrm{~cm}^{-1}$ menunjukkan adanya gugus karboksilat dan kelompok alkena. Sebuah panjang gelombang $1079,53 \mathrm{~cm}^{-1}$ menunjukkan adanya sulfur yang terkandung dalam asam amino pada protein yang diketahui sebagai senyawa aktif antioksidan. Dari data yang diperoleh dapat disimpulkan bahwa pada ekstrak daging buah kopi mengandung senyawa fenol, amida, asam karboksilat, alkena, dan asam amino.

Dari hasil uji aktivitas bakteri memperlihatkan bahwa ekstrak daging buah kopi lebih baik dalam menghambat aktivitas pertumbuhan bakteri S.aureus dibandingkan bakteri E.coli. Hal ini disebabkan karena adanya perbedaan anatomi (struktur) dinding sel bakteri S. aureus dan E.coli. Bakteri E.coli (Gram negatif) memiliki susunan dinding sel yang lebih lengkap, tersusun lapis tiga yang terdiri dari lipoprotein, lipopolisakarida dan peptidoglikan. Kandungan lipid yang tinggi yaitu 11-12\% sangat memungkinkan dapat menghalangi senyawa antibakteri untuk masuk kedalamnya. Sedangkan bakteri S. aureus (Gram positif) memiliki susunan dinding sel yang lebih sederhana berlapis tunggal dengan kandungan lipid rendah yaitu 1-4\% (Melki et al. 2011), sehingga sangat memudahkan senyawa antibakteri untuk merusak dinding sel dan masuk kedalamnya.

Jika ditinjau dari data yang dihasilkan dapat dilihat juga bahwa konsentrasi yang besar pada larutan uji yang digunakan, maka semakin besar pula zona hambat yang dihasilkan. Hal ini disebabkan karena kadar senyawa yang terkandung didalamnya juga semakin tinggi, sehingga lebih kuat dalam menghambat pertumbuhan bakteri(Pelczar \& Chan 1988). Hal ini diperkuat dengan pernyataan Melki et al (2011), bahwa dengan semakin meningkatnya konsentrasi suatu zat dalam suatu larutan (sampel), maka akan menyebabkan peningkatan pula terhadap kandungan senyawa aktif, sehingga kemampuannya untuk membunuh bakteri juga semakin besar (Melki, et al., 2011).

\section{SIMPULAN}

Berdasarkan hasil penelitian yang telah dilakukan dapat disimpulkan bahwa ekstrak yang dihasilkan dari daging buah kopi Robusta (Coffea robusta) memiliki kemampuan menghambat pertumbuhan bakteri S.aureus dan E.coli. Kemudian konsentrasi terbaik pada ekstrak daging buah kopi Robusta (Coffea robusta) pada penelitian ini pertumbuhan bakteri S.aureus dan E.coli adalah dengan konsentrasi 3\% sehingga sangat baik digunakan sebagai antioksidan penghambat laju aktivitas bakteri bahan dasar pembuatan kosmetik masker wajah.

\section{SARAN}

Penelitian berikutnya akan dilakukan uji klinis terhadap ekstrak yang dihasilkan dari daging buah kopi Robusta (Coffea robusta L.) sehingga peneliti dapat memperoleh Hak Kekayaan Intelektual dari penelitian yang telah dilakukan.

\section{DAFTAR PUSTAKA}

Abdillah, S. et al. 2015. Phytochemical Screening and Antimalarial Activity of Some Plants Traditionally Used Indonesia. Asian Pacific Journal of Tropical Disease, 5(6), pp.454-457.

http://dx.doi.org/10.1016/S22221808(15)60814-3.

Draelos, Z.D. 2014. Facial skin care products and cosmetics. Clinics in Dermatology, 32(6), pp.809-812. 
http://dx.doi.org/10.1016/j.clindermatol.20 14.02.020.

Duangjai, A. et al. 2016. Comparison of antioxidant, antimicrobial activities and chemical profiles of three coffee (Coffea arabica L.) pulp aqueous extracts. Integrative Medicine Research, 5(4), pp.18.

http://linkinghub.elsevier.com/retrieve/pii/ S2213422016300932.

Fardiaz, S. 1995. Antimicrobial Activity of Coffee (Coffea robusta) Extract. ASEAN Food Journal, 10(3), pp.1003-106.

Harborne, J.B. 1984. Phytochemical Methods A Guide To Modern Techniques of Plant Analysis Second Edi., New York: Chapman and Hall.

Harmandini, F. 2009. Manfaat Kopi Untuk Mencegah Berbagai Macam Penyakit. Female Kompas. http://female.kompas.com/read/2009/07/27 /11533750/manfaat.kopi.untuk.mencegah.b erbagai.penyakit (Diakses pada 1 Januari 2016).

Je, Y. et al. 2011. A Prospective Cohort Study of Coffee Consumption and Risk of Endometrial Cancer over a 26-Year Follow-Up. American Association for Cancer Research, pp.2487-2496.

Mahesa, M.F. 2012. Esterifikasi Senyawa Polifenol Dari Ekstrak Kulit Biji Kopi Dengan Asam p-Hidroksibenzoat Dengan Menggunakan Katalis $\mathrm{SiO} 2-\mathrm{H}_{2} \mathrm{SO}_{4}$. Universitas Indonesia.

Melki, EP, W.A. \& Kurniati. 2011. Uji Antibakteri Ekstrak Gracilaria sp (Rumput Laut) terhadap Bakteri Escherichia coli dan Staphylococcus aureus.

Najiyati, S. \& Danarti. 2001. Kopi Budidaya dan Penanganan Lepas Panen Cetakan 11. Jakarta.
Patay, E.B. et al. 2016. Antioxidant potential, tannin and polyphenol contents of seed and pericarp of three Coffea species. Asian Pacific Journal of Tropical Medicine, 9(4), pp.366-371.

http://dx.doi.org/10.1016/j.apjtm.2016.03.0 14.

Pelczar, J.M. \& Chan, E.C.S. 1988. Dasar-dasar Mikrobiologi Kedua. R. S. Hadioetomo, ed., Jakarta: Universitas Indonesia-Press.

Pujiyanto. 2007. Pemanfaatan Kulit Buah Kopi dan Bahan Mineral Sebagai Amelioran Tanah Alami. Pelita Perkebunan, 23, pp.159-172.

Suoth, E., Kaempe, H. \& Tampi, A. 2013. Evaluasi Kandungan Total Polifenol dan Isolasi Senyawa Flavonoid Pada Daun GEdi Merah (Abelmoschus monihot L.). Chem. Prog., 6(2), pp.86-91.

Suwarto \& Octavianty, Y. 2010. Budi Daya 12 Tanaman Perkebunan Unggulan. Jakarta: Penebar Swadaya.

va Brigitta Patay, É., í mea Bencsik, T. \& ó ra Papp, N. 2016. Phytochemical overview and medicinal importance of Coffea species from the past until now. Asian Pacific Journal of Tropical Medicine, 9(9), pp.1-5.

Watson, R.R. 2014. Polyphenols in Plants: Isolation, Purification and Extract Preparation First Edit., London: Academic Press, Elvesier.

Widyotomo, S. \& Sri, M. 2006. Ekstraksi Kafein Dari Dalam Biji Kopi. Warta Pusat Penelitian Kopi dan Kakao Indonesia, 22(3), pp.133-141.

Widyotomo, S. \& Sri, M. 2007. Senyawa Penting Pada Biji Kopi. Warta Pusat Penelitian Kopi dan Kakao Indonesia, 23(1), pp.4450 . 